\title{
Konseptualisme dan Validasi Instrumen Narimo Ing Pandum \\ (Studi pada SMK Jetis Perguruan Tamansiswa Yogyakarta)
}

\section{Prayekti}

\author{
Universitas Sarjana Wiyata Taman Siswa Yogyakarta \\ Email : yekti@ustjogja.ac.id
}

\begin{abstract}
Tujuan penelitian ini adalah untuk memvalidasi instrumen narimo ing pandum. Adapun populasi penelitian adalah guru dilingkungan Perguruan Tamansiswa Yogyakarta, dengan sampel sebanyak 30 orang. Untuk mengumpulkan data menggunakan kuisioner.

Hasil penelitian dengan uij validitas menunjukkan bahwa instrumen narimo ing pandum mempunyai validitas karena > 0,5. Untuk hasil uji reliabiltas dengan Cronbach's Alpha 0,928, telah memenuhi persyaratan karena >0,60.
\end{abstract}

Keywords: Nrimo ing pandum

(C) 2019 JBTI. All rights reserved

Article history : Received 27 Jul 2018; Revised 20 Agt 2018; Accepted 20 Sep 2018

\section{PENDAHULUAN}

Nrimo ing pandum merupakan salah satu nilai budaya yang dikenal secara luas oleh masyarakat Jawa (Endraswara, 2012). Ditekankan oleh Koentjaraningrat (Endraswara, 2012), bahwa sikap Nrimo ing pandum berkaitan erat dengan aspek spiritual yang telah melahirkan sebuah nilai fundamental dan tidak lekang ditelan jaman. Penelitian yang dilakukan Herdiana dan Trisepdiana (2013) tentang kesehatan mental narapidana bersuku jawa dilihat dari konsep kepribadian narimo memperoleh hasil bahwa narimo merupakan aspek internal dalam diri sesorang yang berlatar belakang suku jawa dan mempengaruhi kesehatan mental para narapidana tersebut. Dengan demikian narimo merupakan falsafah jawa yang merupakan pribumisasi dari konstruk penerimaan diri (Herdiana dan Trisepdiana, 2013).

Nrimo ing pandum menurut Prasetyo (2014) adalah sebuah sikap penerimaan secara penuh terhadap berbagai kejadian pada masa lalu, masa sekarang serta segala kemungkinan yang bisa terjadi pada masa yang akan datang. Hal ini merupakan upaya untuk mengurangi kekecewaan apabila yang terjadi kemudian ternyata tidak sesuai dengan apa yang diharapkan (Endraswara, 2012; Soesilo, 2003; Rachmatullah, 2010).

Sikap nrimo ing pandum menjadi ciri yang cukup kuat pada pribadi individu dengan latar belakang budaya Jawa (Martiarini, 2012). Sikap nrimo ing pandum menuntun manusia untuk senantiasa bersyukur serta sabar dalam menerima berbagai macam cobaan kehidupan (bebendhu) (Endraswara, 2012; Suratno \& Asiyanto, 2009). Pada saat individu dipenuhi oleh rasa narima, sukur dan terima kasih, maka tubuh akan menjadi rileks. Kondisi rileks dapat memberikan pemijatan halus pada berbagai kelenjar tubuh, menurunkan produksi kortisol dalam darah serta menyeimbangkan pengeluaran hormon sehingga memberikan keseimbangan emosi dan ketenangan pikiran (Davis, dkk. 1995). Sebagai hasilnya, manusia akan mendapatkan ketentraman serta kemampuan menyesuaikan diri terhadap dinamisasi kehidupan yang kemudian melahirkan kebahagiaan (Casmini, 2011; Dharmawati, 2011; Endraswara, 2012). Menurut Ryff dan Keyes (2002), kebahagiaan merupakan Outcome variable dari kesejahteraan psikologis (psychological well-being). Tujuan penelitian ini adalah untuk memvalidasi instrumen narimo ing pandum 


\section{KAJIAN TEORI}

\section{a. Pengertian narima ing pandum}

Panggabean dkk (2014) menjelaskan bahwa konsep nrimo yang berasal dari Filosofi Jawa merupakan satu konsep yang positif yang dicerminkan melalui sikap yang tenang, tidak gegabah, dan menerima apapun yang terjadi dalam hidup sehingga mampu memunculkan sikap positif lainnya yang berupa rasa toleransi. Selain itu narimo merupakan salah satu standar budaya masyarakat Indonesia yang mampu digunakan sebagai strategi dalam menghadapi era global ini. Dalam bukunya yang berjudul Kearifan Lokal Keunggulan Global Cakrawala Baru di Era Globalisasi.

Menurut Wulandari (2017), sikap narimo menunjukkan sikap pengendalian diri yang kuat. Rasionalnya dengan memiliki sikap nrimo masyarakat Jawa berupaya untuk mengendalikan dirinya agar tidak bersikap secara berlebihan dengan marah, kecewa, rendah diri, dan putus asa, melainkan bersikap tenang dan berfokus untuk mencari penyelesaian masalah. Udasmoro (1999) menjelaskan bahwa pengendalian diri manusia Jawa yang utama adalah pengendalian terhadap nafsu dan angkara karena keduanya dianggap akan mengombangambingkan kehidupan manusia sehingga emosi meledak-ledak yang merupakan nafsu manusia yang amat dihindari oleh orang Jawa. Dengan demikian nrimo ing pandum merupakan salah satu pegangan hidup masyarakat Jawa agar dapat menghadapi hidup dengan tenang dan tidak terbawa hawa nafsu.

Narimo adalah sebuah keyakinan bahwa manungsa sakdrema nglakoni urip (manusia hanya sekedar menjalani hidup) dan Gusti kang wenang nemtoake (Tuhan yang berwenang menentukan) (Suratno \& Astiyanto, 2009).

Narimo artinya menerima. Menurut Herdiana dan Trisepdiana, 2013, narimo didefinisikan sebagai ketenangan dalam menyelesaikan masalah, gambaran respon afektif dan kognitif seseorang dalam menyelesaikan masalah, dan kemampuan seseorang untuk melakukan introspeksi diri bahkan saat seseorang itu sedang dihadapkan dalam sebuah masalah atau cobaan dari Tuhan. De jong, 1976 (Heryadi, 2015) mengutip melalui kitab "sasangka djati" bahwa konsep narimo ini merupakan suatu keadaan atau titik dimana individu mampu melampaui perasaan (afektif) positif yang diwakilkan oleh kata "ketenangan". Ketenangan yang dimaksud dalam konteks narimo adalah kesanggupan seorang manusia untuk menerima segala sesuatu yang hadir di dalam hidupnya.

Menurut Chaplin, 2004 (Heryadi, 2015) penerimaan diri adalah sikap yang merupakan rasa puas pada kualitas dan bakat, serta pengakuan akan keterbatasan diri. Pengakuan akan keterbatasan diri ini tidak diikuti dengan perasaan malu ataupun bersalah. Individu ini akan menerima kodrat mereka apa adanya.

Nrimo ing Pandum, narimo artinya menerima sedangkan Pandum artinya pemberian. Jadi Nrimo ing Pandum memiliki arti menerima segala pemberian apa adanya tanpa menuntut yang lebih dari itu. Menurut Sudaryanto (2005) narima ing pandum (NIP) merupakan menerima takdir dengan ikhlas. Terkait dengan itu dari penelitian Sudaryanto (2005) bahwa keyakinan para Abdi Dalem bahwa Urip mung mampir ngombe (hidup hanyalah tempat transit sebentar) membangun keyakinan para abdi dalem akan narima ing pandum yaitu menerima takdir dengan ikhlas. Menerima keadaan diri kita dan keluarga apa adanya dari segala aspeknya merupakan implementasi dari nrimo dan penerimaan diri. Selalu apa adanya dan mensyukuri setiap apa yang menjadi keberadaan kita adalah upaya menuju kebahagiaan dengan tidak pernah melupakan rasa syukur kita.

Menurut Koentjaraningrat, 1990, (dalam Nugroho, 2018), narimo ing pandhum adalah sebuah sikap penerimaan secara penuh terhadap berbagai kejadian pada masa lalu, masa sekarang serta segala kemungkinan yang bisa terjadi pada masa yang akan datang. Hal ini merupakan upaya untuk mengurangi kekecewaan apabila yang terjadi kemudian ternyata tidak sesuai dengan apa yang diharapkan (Endraswara, 2012; Soesilo, 2003; Rachmatullah, 2010). Selain itu Hidayat dan Wijanarko (2008) dalam Nugroho (2018) mengartikan narimo ing 
pandhum sebagai penerimaan atas seluruh pemberian dalam kehidupan ini, tanpa tuntutan dan menerima dengan apa adanya secara keseluruhan.

Menurut Endraswara (2012), narimo ing pandum yang berarti mau menerima kenyataan juga merupakan bagian dari kepribadian orang jawa dan cerminan dari lima sikap orang jawa yang disebut Panca sila ( Rila, Narimo, Temen, Sabar, Budi Luhur) Konsep diatas menggambarkan bahwa orang jawa merupakan pribadi yang memiliki kemampuan untuk ikhlas, menerima apa adanya, berkomitmen, sabar, dan berbudi luhur. Hal ini dapat diartikan bahwa segala situasi yang ada atau datang, orang jawa akan selalu menerimanya dengan baik. Ketika datang musibah akan diterima dengan baik dengan melakukan intropeksi diri tentang kesalahannya dan berusaha menjadi lebih baik lagi. Sedangkan jika datang sesuatu yang menyenangkan akan di terima dengan bersyukur. Contoh dari penerapan nilai budaya tersebut adalah orang jawa akan selalu mengadakan syukuran dengan jamuan makan untuk saudara ataupun tetangganya dalam keaadaan apapun baik susah maupun senang. Inti dari nilai budaya narimo ing pandhum adalah adanya kesadaran diri dan pemahaman diri seseorang untuk bisa mewujudkan eksistensi hidupnya. Segala sesuatu pasti ada manfaat dan kebaikannya. Seseorang akan memperoleh kesenangan ketika sudah melalului kesulitan-kesulitan. Penderitaan adalah salah satu cara untuk mewujudkan eksistensi hidup, sehingga segala sesuatu harus diterima dengan baik. Berdasarkan hasil penelitian nilai budaya narimo ing pandhum memberikan pengaruh positif ketika sesorang dalam kondisi yang sulit dan mempunyai kecemasan yang tinggi.

Sikap nrimo ing pandum sudah sangat melekat dalam kesadaran sosial dan sangat cocok diinternalisasikan pada masyarakat Jawa (Koentjaraningrat, 1990 dalam Nugroho, 2018). Salah satu usaha untuk menginternalisasikan sikap NIP adalah melalui program psikoedukasi. Berbagai penelitian telah menunjukkan keuntungan psikoedukasi, yaitu meningkatkan sikap penerimaan, strategi koping, pemecahan masalah, menurunkan stres, dan membawa perubahan positif (Oshodi, dkk. 2012), membantu mengurangi beban, meningkatkan kualitas pendampingan fisik dan mental pendamping (Diener, dkk. 2011), meningkatkan fungsi sosial, kepuasan hidup, pengetahuan, harapan serta keberdayaan pada ODS, menurunkan distress, peningkatan wellbeing dan fungsi keluarga pendamping secara keseluruhan (Diener, dkk. 2011). Hal ini juga dapat diperkuat dengan memberikan pengelolaan stres dan teknik coping yang lain, seperti pendekatan naratif dan meditasi (Ryff, dkk. 2002). Melalui pendekatan naratif, partisipan didorong untuk menceritakan pengalaman yang berkaitan dengan keadaan yang selama ini dihadapinya. Hal ini dapat membantu pendamping untuk mengenali kekuatan diri, potensi, serta berbagai kemungkinan untuk bertindak dan tumbuh (Ryff, dkk. 2002). Sedangkan meditasi dapat membantu partisipan untuk secara sadar menjadi rileks. Hal tersebut menyebabkan pikiran berubah menjadi tenang, rileks, dan terpusat (Dorian, dkk. 2008; Endraswara, 2012). Jadi narimo ing pandum memiliki arti menerima segala pemberian dengan bersyukur serta sabar (Endraswara, 2012; Suratno \& Asiyanto, 2009; Heryadi, 2013).

\section{b. Indikator narimo ing Pandum}

Sikap nrimo ing Pandum terdiri atas beberapa elemen nilai, yaitu sukur (kebersyukuran), sabar (kesabaran) dan narima (penerimaan) (Heryadi, 2013; Soesilo, 2003; Fananie, 2005; Mulyana, 2006; Widayat, 2006; Suratno \& Astiyanto, 2009; Endraswara, 2012).

Elemen sukur, sabar, dan narimo yang kuat menyebabkan sikap nrimo ing pandum menjadi mudah terpatri pada jiwa seseorang sehingga dapat menerima segala keadaan dengan lapang dada serta tidak terjebak memikirkan pengalaman pahit masa lalu dan ketidakpastian masa depan (Endraswara, 2012; Mulyana, 2006; Widayat, 2006).

Syukur (sukur) merupakan sebuah bentuk emosi atau perasaan positif atas limpahan anugrah yang telah diterima, kemudian berkembang menjadi suatu sikap serta kebiasaan dan akhirnya mempengaruhi seseorang dalam bereaksi terhadap lingkungannya (Emmons \& McCullough, 2003).

Sabar merupakan sebuah sandaran nilai ketahanan yang banyak digunakan ketika orang menghadapi persoalan psikologis, misalnya menghadapi situasi yang penuh tekanan (stress), 
menghadapi persoalan, musibah atau ketika sedang mengalami kondisi emosi marah (Subandi, 2011). Dari segi istilah, sabar adalah menahan diri dari sifat kegundahan dan rasa emosi, kemudian menahan lisan dari keluh kesah serta menahan anggota tubuh dari perbuatan yang tidak terarah (Sari, 2015). Sabar sebagai salah satu dasar dan fondasi akhlak dalam agama Islam yang lurus. Fondasi itu adalah kesabaran yang mempengaruhi seluruh sendi kehidupan manusia. Sesungguhnya kesempurnaan agama dan dunia ini erat hubungannya dengan kesabaran. Kemerosotan keduanya juga erat hubungannya dengan kesabaran. Orang yang sabar akan memiliki sifat tulus dan ikhlas dalam berinteraksi dengan semua orang, tanpa melihat perbedaan. Menurut Muhammad (2006: 154) ikhlas yaitu sikap murni dalam tingkah laku dan perbuatan, semata-mata demi memperoleh keridhaan Allah dan bebas dari pamrih lahir dan batin, tertutup maupun terbuka.

Sikap sabar memiliki pengaruh yang sangat besar terhadap hubungan yang hebat. Tanpa memiliki sikap sabar, kita akan sangat mudah stres oleh berbagai keadaan. Sikap sabar adalah perilaku hebat untuk mendapatkan jalan menuju kebahagiaan, kedamaian dan kenyamanan. Sikap sabar akan menghindarkan kita dari perilaku kekerasan.

Ayat-ayat al-Quran Yang Menegaskan Sabar: Allah SWT berfirman "Wahai orangorang yang beriman, bersabarlah kamu dan kuatkanlah kesabaranmu” (Q.S. Ali Imran:200). "Tetapi orang yang bersabar dan mema`afkan sesungguhnya (perbuatan) yang demikian itu termasuk hal-hal yang diutamakan.” (Asy-Syuuraa:43)

Menurut Al-Jauziyyah (2006) dikutip oleh Uyun (2015) karakteristik orang yang sabar adalah 1) mampu mengendalikan diri untuk tidak mengatakan apa pun yang seharusnya tidak dikatakan, dan mereka memiliki kontrol diri dan tidak mudah untuk membangkitkan emosi. 2) Orang-orang yang sabar mampu menahan diri dari amarah, oleh karena itu mereka dapat menghadapi masalah dengan tenang, dan kemudian mereka lebih bisa menghindari kecemasan. 3) Orang yang sabar memiliki kemampuan tidak terburu-buru untuk melakukan sesuatu, dan dapat melakukan apa saja dengan tenang. 4) Kesabaran adalah keberanian untuk menghadapi masalah, sehingga tidak akan menghindari kesulitan, tetapi menghadapi semuanya dengan penuh percaya diri dan tetap tenang. Mereka tidak akan khawatir tentang apa pun yang terjadi. 5) Orang dapat mengendalikan diri untuk menghindari kemalasan, oleh karena itu mereka dapat melakukan sesuatu jelas dan tidak dapat diterima oleh hal-hal negatif. 6) Orang-orang yang sabar dapat bertahan diri dari berbagai kesenangan dunia, oleh karena itu mereka dapat dengan mudah menerima apa saja yang mereka miliki. Mereka tidak akan khawatir ketika mereka tidak memiliki hal-hal yang baik. 7) Orang yang sabar bisa menahan diri dari dorongan seksual, karena itu mereka dapat mengontrol motivasi seksual. Mereka tidak akan menjadi cemas ketika harus menunda kepuasan seksual.

Pada tulisan lain Al-Jauziyyah (2006) dalam Uyun (2017) menjelaskan bahwa, secara umum, ada tiga aspek kesabaran, yaitu: 1) Kepatuhan kepada bimbingan Tuhan kepatuhan pada perintah-Nya dan menggabungkan dalam Sunnah Nabi ke seharian kehidupan. 2) Ketaatan untuk menghindari larangan Tuhan. 3) Penerimaan kesulitan, seperti orang yang mampu mengatasi keadaan buruk. Poin ketiga menunjukkan bahwa sabar dikaitkan dengan malapetaka dan kesulitan. Sabar di saat-saat sulit berarti bertahan dengan waktu yang sulit tanpa menyalahkan Allah dan bertanggung jawab untuk mengatasi kesulitan. Kesabaran memungkinkan orang-orang untuk membuat berarti dari kehidupan tanpa perasaan marah, penyesalan, dan penangkapan ketika mereka menghadapi situasi sulit. Berdasarkan perspektif Buddhis terdapat tiga karakteristik kesabaran (Dalai Lama, 1997) yang dikutip oleh Uyun (2017): (1) toleransi berdasarkan kesadaran, penerimaan rasa sakit dan kesulitan hidup; (2) toleransi dari refleksi tentang sifat realitas; (3) toleransi terhadap inju amarah dari orang lain. Orang yang sabar akan mempertahankan kesabaran dan kepercayaan pada Tuhan ketika dihadapkan kesulitan dan bencana.

Narimo artinya menerima. Menurut Herdiana dan Trisepdiana, 2013, narimo didefinisikan sebagai ketenangan dalam menyelesaikan masalah, gambaran respon afektif dan kognitif seseorang dalam menyelesaikan masalah, dan kemampuan seseorang untuk melakukan 
introspeksi diri bahkan saat seseorang itu sedang dihadapkan dalam sebuah masalah atau cobaan dari Tuhan. De jong, 1976 (Heryadi, 2015) mengutip melalui kitab "sasangka djati" bahwa konsep narimo ini merupakan suatu keadaan atau titik dimana individu mampu melampaui perasaan (afektif) positif yang diwakilkan oleh kata "ketenangan". Ketenangan yang dimaksud dalam konteks narimo adalah kesanggupan seorang manusia untuk menerima segala sesuatu yang hadir di dalam hidupnya.

\section{METODE PENELITIAN}

Sebagai variabel dalam penelitian ini yakni narimo ing pandum Adapun indikator dari narimo ing pandum mengacu dari Endraswara (2012) yaitu:

a. Syukur, menerima segala sesuatu dengan senang

b. Sabar, dapat menahan emosi

c. Narimo, menerima segala sesuatu dengan tenang

Dalam penelitian ini, yang menjadi populasi adalah guru di SMK Jetis Perguruan Tamansiswa Yogyakarta. Untuk pengambilan sampel menggunakan metode aksidental (Sekaran, 2011) dengan sampel penelitian sebanyak 30. Untuk mengukur valid tidaknya item variabel pada uji validitas menggunakan Corrected Item-Total Correlation, sedangkan untuk mengetahui konsistensi dari instrument yang dapat dipercaya pada uji reliabilitas menggunakan rumus Alpha Cronbach.

\section{HASIL DAN PEMBAHASAN}

\section{a. Uji validitas}

Berikut hasil uji validitas narimo ing pangdum (NIP) ditunjukkan dengan gambar:

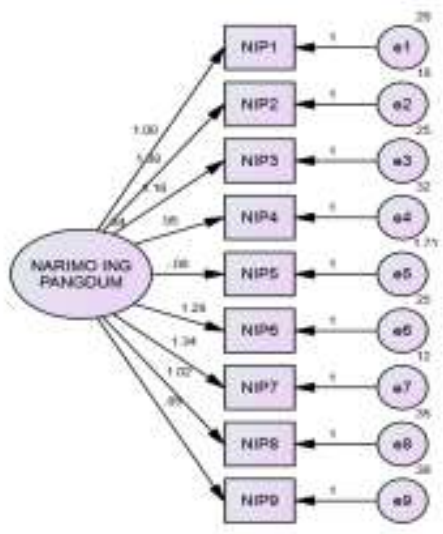

chi-Square $=48.796$

Probabilitas $=.006$ $\mathrm{df}=27$

CMIN/DF $=1.807$

RMSEA $=167$

$\mathrm{GFI}=.773$

$\mathrm{AGFI}=.621$

$\mathrm{CFI}=874$

TLI $=.832$

$\mathrm{NFI}=.767$

Standardized Regression Weights: (Group number 1 - Default model)

Gambar 1: Hasil uji validitas narimo ing pangdum

Selanjutnya hasil uji validitas narimo ing pangdum (NIP) ditunjukkan dalam tabel 1

Tabel 1

Hasil uji validitas narimo ing pangdum (NIP)

\begin{tabular}{lllr}
\hline & & & Estimate \\
\hline NIP1 & $<---$ & NIP & .796 \\
NIP2 & $<---$ & NIP & .884 \\
NIP3 & $<---$ & NIP & .806 \\
NIP4 & $<---$ & NIP & .700 \\
\hline
\end{tabular}




\begin{tabular}{lllr}
\hline & & & Estimate \\
\hline NIP5 & $<---$ & NIP & -.036 \\
NIP6 & $<---$ & NIP & .831 \\
NIP7 & $<---$ & NIP & .914 \\
NIP8 & $<---$ & NIP & .712 \\
NIP9 & $<---$ & NIP & .627 \\
\hline
\end{tabular}

Berdasarkan tabel 1 dapat dilihat bahwa 9 (sembilan) butir (item) pernyataan variabel narimo ing pangdum (NIP) tidak semuanya valid yaitu pada NIP 5 tidak valid. Hal ini dapat dilihat dari kolom korelasi untuk item NIP 5 di bahwa $\mathrm{r}_{\text {hitung }}<0.05$. Menurut Wiyono (2011) jika nilai estimate kurang dari 0,5 maka item tidak valid.

Karena adanya item yang tidak valid maka item yang tidak valid harus dikeluarkan dari variabel tersebut. Sehingga hasil item yang valid pada gambar:

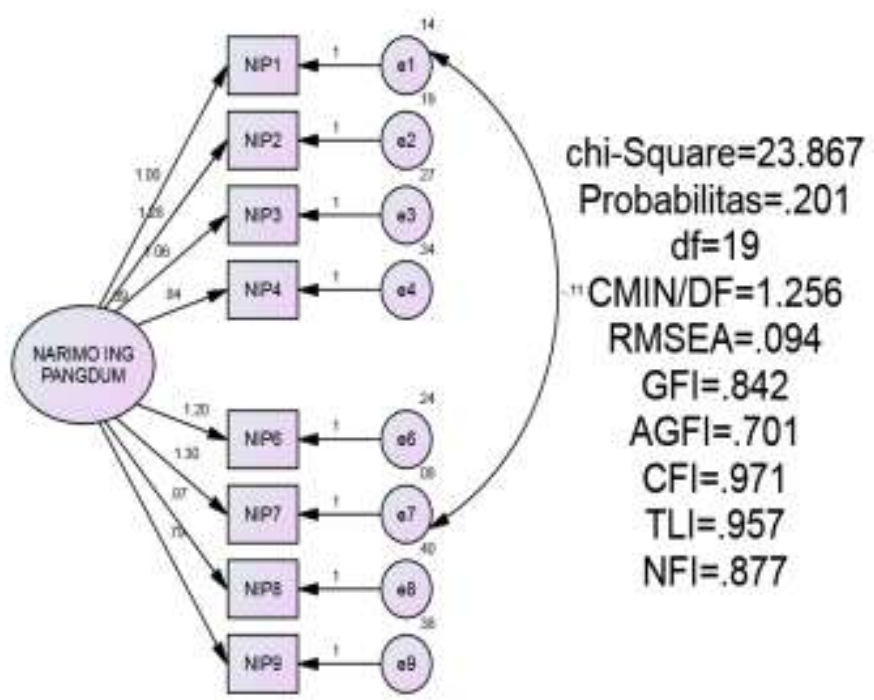

Standardized Regression Weights: (Group number 1 - Default model)

Gambar 2: Hasil validitas narimo ing pangdum

Selanjutnya item narimo ing pangdum yang telah valid diuji kembali, hasil uji validitas narimo ing pangdum ditunjukkan dalam tabel 2

Tabel 2

Hasil validitas narimo ing pangdum (NIP)

\begin{tabular}{lccr}
\hline & & & Estimate \\
\hline NIP1 & $<---$ & NIP & .856 \\
NIP2 & $<---$ & NIP & .881 \\
NIP3 & $<---$ & NIP & .791 \\
NIP4 & $<---$ & NIP & .669 \\
NIP6 & $<---$ & NIP & .839 \\
NIP7 & $<---$ & NIP & .946 \\
NIP8 & $<---$ & NIP & .650 \\
NIP9 & $<---$ & NIP & .630 \\
\hline
\end{tabular}


Berdasarkan tabel 2 diatas dapat dilihat bahwa 8 butir pernyataan dari variabel narimo ing pangdum (NIP) semuanya valid. Hal ini dapat dilihat dari kolom korelasi bahwa $r_{\text {hitung }}>$ 0.05. Hasil uji reliabilitas variabel narimo ing pandum pada Tabel 16

Tabel 3

Uji reliabilitas variabel narimo ing pandum

Cronbach's Alpha Keterangan

$.928 \quad$ Reliabel

Sumber: data diolah 2018.

Cronbach's Alpha 0,928, oleh karena nilai Alpha > 0,60 maka data yang ada dinyatakan reliabel dan layak digunakan. Dengan demikian elemen sukur, sabar, dan narimo sebagai elemen dari nrimo ing pandum dapat diterima. Dengan elemen sukur, sabar, dan narimo sebagai elemen dari nrimo ing pandum yang kuat menyebabkan sikap nrimo ing pandum menjadi mudah terpatri pada jiwa seseorang sehingga dapat menerima segala keadaan dengan lapang dada serta tidak terjebak memikirkan pengalaman pahit masa lalu dan ketidakpastian masa depan (Endraswara, 2012; Mulyana, 2006; Widayat, 2006).

Narimo artinya menerima. Menurut Herdiana dan Trisepdiana, 2013, narimo didefinisikan sebagai ketenangan dalam menyelesaikan masalah, gambaran respon afektif dan kognitif seseorang dalam menyelesaikan masalah, dan kemampuan seseorang untuk melakukan introspeksi diri bahkan saat seseorang itu sedang dihadapkan dalam sebuah masalah atau cobaan dari Tuhan. De jong, 1976 (Heryadi, 2015) mengutip melalui kitab "sasangka djati" bahwa konsep narimo ini merupakan suatu keadaan atau titik dimana individu mampu melampaui perasaan (afektif) positif yang diwakilkan oleh kata "ketenangan". Ketenangan yang dimaksud dalam konteks narimo adalah kesanggupan seorang manusia untuk menerima segala sesuatu yang hadir di dalam hidupnya.

Menurut Endraswara (2012), narimo ing pandum yang berarti mau menerima kenyataan juga merupakan bagian dari kepribadian orang jawa dan cerminan dari lima sikap orang jawa yang disebut Panca sila ( Rila, Narimo, Temen, Sabar, Budi Luhur) Konsep diatas menggambarkan bahwa orang jawa merupakan pribadi yang memiliki kemampuan untuk ikhlas, menerima apa adanya, berkomitmen, sabar, dan berbudi luhur. Hal ini dapat diartikan bahwa segala situasi yang ada atau datang, orang jawa akan selalu menerimanya dengan baik. Ketika datang musibah akan diterima dengan baik dengan melakukan intropeksi diri tentang kesalahannya dan berusaha menjadi lebih baik lagi. Sedangkan jika datang sesuatu yang menyenangkan akan di terima dengan bersyukur. Contoh dari penerapan nilai budaya tersebut adalah orang jawa akan selalu mengadakan syukuran dengan jamuan makan untuk saudara ataupun tetangganya dalam keaadaan apapun baik susah maupun senang. Inti dari nilai budaya narimo ing pandhum adalah adanya kesadaran diri dan pemahaman diri seseorang untuk bisa mewujudkan eksistensi hidupnya. Segala sesuatu pasti ada manfaat dan kebaikannya. Seseorang akan memperoleh kesenangan ketika sudah melalului kesulitan-kesulitan. Penderitaan adalah salah satu cara untuk mewujudkan eksistensi hidup, sehingga segala sesuatu harus diterima dengan baik. Berdasarkan hasil penelitian nilai budaya narimo ing pandhum memberikan pengaruh positif ketika sesorang dalam kondisi yang sulit dan mempunyai kecemasan yang tinggi.

\section{KESIMPULAN}

Berdasarkan hasil uji validitas menunjukkan bahwa dari 8 (delapan) butir (item) pernyataan variabel narimo ing pangdum (NIP) semuanya valid. Hal ini dapat dilihat dari kolom korelasi untuk item NIP di bahwa $\mathrm{r}_{\text {hitung }}>0.05$. Hasil Cronbach's Alpha sebesar 0,928 >0,60 maka data yang ada dinyatakan reliabel dan layak digunakan. 


\section{SARAN}

Implikasi teoritis dari penelitian ini adalah terbuktinya penelitian ini hasil Cronbach's Alpha sebesar 0,928>0,60 maka data yang ada dinyatakan reliabel dan layak digunakan. Menurut Wiyono (2011) jika nilai Alpha > 0,5 maka secara parsial maupun secara komposit dinyatakan reliabel. Dengan demikian elemen sukur, sabar, dan narimo sebagai elemen dari nrimo ing pandum (NIP) dapat diterima.

\section{DAFTAR PUSTAKA}

Casmini. (2011). Kecerdasan Emosi dan Kepribadian Sehat Dalam Konteks Budaya Jawa di Yogyakarta. Disertasi (Tidak Diterbitkan). Yogyakarta: Program Doktor Psikologi Fakultas Psikologi UGM.

Davis, M., Eshelman, E.R dan Matthew, M. (1995). Panduan Relaksasi dan Reduksi Stres Edisi III. Jakarta: Penerbit Buku Kedokteran EGC.

Dharmawati. (2011). Psychological Well Being Wanita Lajang. Skripsi (Tidak Diteritkan). Yogyakarta: Fakultas Psikologi UGM.

Diener, E., Frank, F., Tay, L., \& Biswas Diener, R. (2011). Purpose, Mood, and Pleasure in Predicting Satisfaction Judgement. Social Indicator Research, 15, 187-219.

Dorian, M., Garcia, J.I.R., Lopez, S.R. \& Hernandez, B. (2008). Acceptance and Expressed Emotion in Mexican American Caregivers of Relatives with Schizophrenia. Family Process, 47(2), 215-228.

Endraswara, S. (2012). Falsafah Hidup Jawa: Menggali Mutiara Kebijakan dari Intisari Filsafat Kejawen. Yogyakarta: Cakrawala.

Emmons, R.A., \& McCullough, M.E. (2003). Counting Blessing Versus Burdens: An Experimental Investigationof Gratitude and Subjective Well Being in Daily Life. Journal of Personality and Social Psychology, 84 (2), 377-389.

Fananie, Z. (2005). Restrukturisasi Budaya Jawa Perspektif KGPAA MN I. Surakarta: Muhammadiyah University Press.

Herdiana, I \& Triseptiana, N.A. (2013). Gambaran Kesehatan Mental Narapidana Suku Jawa di Tinjau Dari Konsep Nrimo. Jurnal Psikologi Kepribadian dan Sosial.Volume No.1.April 2013.

Heryadi, Adi.2015. Nrimo dan Penerimaan Diri : Upaya Menuju Kebahagiaan. Makalah ini disampaikan pada Talkshow Bahagia Itu Mudah yang diselenggarakan oleh Stipsi Carrer Centre (SCC) dalam rangka Hari Kesehatan Mental Sedunia tanggal 10 Oktober 2015.

Martiarini N. (2012). Pengatasan Kelelahan Ego (Ego Depletion) Pada Individu Dalam Konteks Budaya Jawa. Tesis (Tidak Diterbitkan). Yogyakarta: Fakultas Psikologi UGM.

Muhammad Alim. 2006. Pendidikan Agama Islam: Upaya Pembentukan Pemikiran dan Kepribadian Muslim. Bandung: PT Remaja Rosdakarya Offset Bandung.

Mulyana. (2006). Spiritualitas Jawa: Meraba Dimensi dan Pergulatan Religiusitas Orang Jawa. Jurnal Kebudayaan Jawa, 1(2), 1-13.

Nugroho, I.S. 2018. Pendekatan Eksistensial-Humanistik berbasis nilai Budaya Jawa "narimo ing pandhum" untuk mereduksi kecemasan remaja di era disrupsi. Prosiding SNBK (Seminar Nasional Bimbingan dan Konseling) 2 (1), 46 - 54.

Oshodi, Y., Adeyemi, J., Alna, O. S., \& Umeh, C. (2012). Burden and Psychological Effects : Caregiver Experiences in a Psychiatric Out patient Unit in Lagos, Nigeria. African Journal of Psychiatry, 15, 99-105.

Palupi, M. \& Tjahjono, H.K. 2016. Model of religiousity and organizational justice: the impact on commitment and dysfunctional behavior. Proceedings of the 27th International Business Information Management Association Conference, Italy, p. 1781-1790 
Panggabean, H 2014. Kearifan Lokal Keunggulan Global Cakrawala Baru di Era Globalisasi. Jakarta: PT Elex Media Komputindo

Prasetyo, N. H. (2014). "Narimo Ing Pandum” Intervention Program To

Enhance Psychological Well-Being Of Family Caregiver Of Schizophrenic Patient. Jurnal Intervensi Psikologi Vol. 6 No. 2 Desember 2014.

Prasetyo \& Subandi. 2014. Program Intervensi Narimo Ing Pandum untuk Meningkatkan Kesejahteraan Psikologis Keluarga Pasien Skizofrenia. Jurnal Intervensi Psikologi Vol. 6 No. 2 151-170.

Rachmatullah, A. (2010). Falsafah Hidup Jawa. Yogyakarta: Logung Pustaka.

Ryff, CD., \& Keyes, CLM. (2002). The Structure of Psychological Well Being Revisited. Journal of Personality and Social Psychology, 69(4), 719-727.

Sari, Jayanti Armida, Aldri Frinaldi, Syamsir. 2015. Pengaruh Pemahaman Nilai Agama Islam Terhadap Budaya Kerja Pegawai Negeri Sipil Di Kabupaten Pasaman Barat. Jurnal Humanus Vol. XIV No.2 Th. 2015

Sekaran, U, 2011. Research Methods for bussines. Edisi 1 \& 2, Jakarta: Salemba

Subandi. (2011). Sabar: Sebuah Konsep Psikologi. Jurnal Psikologi UGM, 3(2), 215-227.

Sudaryanto, A. (2008). Hak dan Kewajiban Abdi Dalem Dalam Pemerintahan Kraton Yogyakarta. Jurnal Mimbar Hukum Volume 20, Nomor 1, Februari 2008, Hal 1-191.

Soesilo. (2003). Piwulang UngkapanOrang Jawa. Jakarta: Yayasan Yusula.

Suratno, P. \& Astiyanto, H. (2009). Gusti Ora Sare : 90 Mutiara Nilai Kearifan Budaya Jawa. Yogyakarta : Adiwacana.

Tjahjono, H.K. 2011. The configuration among social capital, distributive and procedural justice and its consequences to individual satisfaction. International Journal of Information and Management Sciences, 22(1): 87-103.

Tjahjono, H.K. (2014). The fairness of organization's performance appraisal, social capital and the impact toward affective commitment. International Journal of Administrative Science \& Organization, 21(3): 173-179

Udasmoro, W. 1999. Memahami Karakteristik unconscious Filosofi Jawa Melalui Tokoh Wayang Bima. Jurnal Humaniora No. 12 September-Desember 1999, halaman 43.

Uyun, Q. 2015.The Effect Of Sabr (Patience) And Salat (Prayer) On Resilience, Psychopathological Symptoms, Just World Belief, And Coping After Merapi Eruption 2010 In The Region Of Yogyakarta (Indonesia). Disertasi (tidak dipublikasikan). 